\title{
Influence of flaxseed with rumen undegradable protein level on milk yield, milk fatty acids and blood metabolites in transition ewes
}

\author{
Rahmat Ababakri ${ }^{1}$, Omid Dayani ${ }^{1 *}$, Amin Khezri ${ }^{1}$ and Abbas-Ali Naserian ${ }^{2}$ \\ ${ }^{1}$ Department of Animal Science, College of Agriculture, Shahid Bahonar University of Kerman, Kerman \\ 76169-14111, Iran \\ ${ }^{2}$ Department of Animal Science, College of Agriculture, Ferdowsi University of Mashhad, Mashhad 91775- \\ 1163, Iran
}

Received: Nov 15, 2020

Revised: Jan 21, 2021

Accepted: Feb 25, 2021

*Corresponding author

Omid Dayani

Department of Animal Science,

College of Agriculture, Shahid Bahonar University of Kerman, Kerman 7616914111, Iran.

Tel: +98-34-31322693

E-mail: odayani@uk.ac.ir

Copyright () 2021 Korean Society of Animal Sciences and Technology. This is an Open Access article distributed under the terms of the Creative Commons Attribution Non-Commercial License (http:// creativecommons.org/licenses/by$\mathrm{nc} / 4.0 /$ ) which permits unrestricted non-commercial use, distribution, and reproduction in any medium, provided the original work is properly cited.

ORCID

Rahmat Ababakri

https://orcid.org/0000-0001-6486-6899 Omid Dayani

https://orcid.org/0000-0002-7067-8242 Amin Khezri

https://orcid.org/0000-0002-5371-9831

Abbas-Ali Naserian

https://orcid.org/0000-0003-1179-6262

Competing interests

No potential conflict of interest relevant to this article was reported.

Funding sources

Not applicable.

\section{Abstract}

An experiment was conducted to determine the effects of two levels of rumen undegradable protein (RUP) without or with whole or extruded flaxseed on milk yield, milk component, milk fatty acids (FAs) profile and plasma metabolites in transition ewes. Three weeks before and after lambing, seventy-two Baluchi ewes were used in a completely randomized design with a $3 \times 2$ factorial arrangement of treatments. The treatments contained 1) no flaxseed $+20 \%$ RUP (no flaxseed, low RUP [NFLR]); 2) no flaxseed + 40\% RUP (no flaxseed, high RUP [NFHR]); 3) $10 \%$ whole flaxseed $+20 \%$ RUP (whole flaxseed, low RUP [WFLR]); 4) $10 \%$ whole flaxseed + $40 \%$ RUP (whole flaxseed, high RUP [WFHR]); 5) 10\% extruded flaxseed $+20 \%$ RUP (extruded flaxseed, low RUP [EFLR]), and 6) 10\% extruded flaxseed $+40 \%$ RUP (extruded flaxseed, high RUP [EFHR]). Ewes fed 10\% extruded flaxseed exhibited higher $(p<0.001)$ dry matter intake (DMI) and colostrum yield $(p<0.1)$ compared to other treatments. Two types of flaxseed and RUP levels had no significant effect on milk yield, but milk fat and protein contents decreased and increased in diets containing 40\% RUP, respectively. Ewes fed extruded flaxseed produced milk with lower concentrations of saturated fatty acids (SFA) and higher $\alpha$-linolenic and linoleic acids and also polyunsaturated fatty acids (PUFA) compared to other groups $(p<0.05)$. During post-lambing, the ewes fed diets containing flaxseed exhibited higher concentration of serum non-esterified FAs (NEFA) compared to diets without flaxseed $(p<0.01)$. The concentration of serum $\beta$-hydroxybutyric acid (BHBA) decreased in the diets containing flaxseed types at pre-lambing, but increased in diets containing extruded flaxseed at post-lambing $(p<0.01)$. The serum glucose concentration of ewes (pre and post-lambing) which consumed diets containing extruded flaxseed or $40 \%$ RUP increased, but blood urea concentration was elevated following supplementation of diet with whole flaxseed or $40 \%$ RUP $(p<0.001)$. In conclusion, utilization of $10 \%$ extruded flaxseed in the diets of transition ewes had positive effects on animal performance with favorable changes in milk FAs profile. However, there is no considerable advantage to supply more than $20 \%$ RUP level in the diet of transition dairy sheep.

Keywords: Transition period, Rumen undegradable protein, Flaxseed, Colostrum, Milk fatty acids 
Acknowledgements

The authors would like to thank the Shahid

Bahonar University of Kerman for the

financial support of this research. We also

gratefully acknowledge the assistance of Dr

Mohsen Kazemi and Dr. Amir Mokhtarpour in editing this paper.

\section{Availability of data and material Upon reasonable request, the datasets of this study can be available from the corresponding author.}

\section{Authors' contributions}

Conceptualization: Ababakri R, Dayani O.

Data curation: Ababakri R, Dayani $O$.

Formal analysis: Ababakri R, Dayani O.

Methodology: Ababakri R, Dayani O,

Naserian AA.

Writing-original draft: Ababakri R, Dayani O.

Writing-review \& editing: Ababakri R, Dayani $O$, Khezri A, Naserian AA

Ethics approval and consent to participate Animals were cared according to the guidelines by the Iranian Council of Animal Care (Guide to the Care and Use of Experimental Animals, Isfahan University of Technology) (Approval no: 1284113).

\section{INTRODUCTION}

Ewe's nutrition management during the transition period is a crucial factor influencing lambs' birth weight, udder development, and milk and colostrum yield. Given that $80 \%$ of fetus growth takes place at two last months of pregnancy, the nutrient requirements of ewes increase significantly during this period [1]. Flaxseed (Linumusitatissimum) contains approximately $20 \%$ crude protein (CP) and $40 \%$ oil on dry matter (DM) basis [2] and it was shown to increase the yield of milk and protein [3]. Feeding animals with flaxseed, as a source of n-3 polyunsaturated fatty acids (PUFA), is also an effective way to improve feed intake and energy balance [4]. Recently, more attention has been paid to flaxseed as a lipid supplement in the ruminant diets due to its high content of $\alpha$-linolenic acid (over 55\% of total fatty acid [FA]) [5], leading to an increase in the concentrations of long-chain fatty acids (LCFA) and PUFA (especially C18:3n3), and decrease the concentration of short-chain fatty acids (SCFA) and medium-chain fatty acids (MCFA) and saturated fatty acids (SFA) in milk fat of dairy cows [6], goats [7] and sheep [8]. Maamouri et al. [9] reported that extruded linseed could block the terminal biohydrogenation steps, thus increasing the ratio of transintermediate such as cis-9 trans-11 C18:2 and trans-10 cis-12 C18:2 [10]. Therefore, incorporating flaxseed in ruminant diets can contribute to the prevention of cardiovascular diseases [11] and the modulation of immune and inflammatory responses [12].

It has been reported that high levels of dietary rumen undegradable protein (RUP) and oil can be effective on the dietary protein, milk yield and milk protein efficiencies [3]. Feeding cows with RUP would result in the greater flow of amino acids to the small intestine, increasing intestinal absorption availability [13]. Furthermore, increasing digestion and absorption of proteins in the small intestine following the addition of vegetable oil was previously reported [14]. Therefore, increasing the amounts of dietary RUP and oil or oilseeds may improve the overall use of dietary protein, resulting in increased milk production and protein concentration. Moreover, several studies suggested that providing excess protein in the diet of ewes during late pregnancy is vital for fetus growth, udder development and colostrum and milk yield, and consequently the lamb growth and survival $[15,16]$.

To the best of our knowledge there is little information regarding the interaction between different RUP level and different flaxseed types during transition period of ewes. Thus, we hypothesize that supplementation of ewe's diets with flaxseeds and RUP in the late gestation may enhance the performance of pregnant ewes. Therefore, the main objective of the present study was to investigate the effects of feeding diets without or with processed flaxseed (whole or extruded) and two theoretical levels of RUP (20\% and 40\%) on milk yield, milk composition, colostrum yield, milk FAs profile and some plasma metabolites of Baluchi ewes during the transition period.

\section{MATERIALS AND METHODS}

\section{Animals, diets and experimental design}

This project was carried out at the sheep raising center of Torbat-e-Jam located on the north east part of Iran at $35.2317^{\circ} \mathrm{N}$ latitude and $60.6401^{\circ} \mathrm{E}$ longitude from November 2018 to January 2019. All animals were housed and treated following the guidelines suggested by Iranian Council of Animal Care [17]. Seventy-two multiparous Baluchi ewes ( $48.7 \pm 2.8 \mathrm{~kg}$ of body weight [BW] and $2-3$ years old at the beginning of experiment) were randomly allocated to 6 groups ( $n=12$ ewes in each group) in a completely randomized design with a $3 \times 2$ factorial arrangements. Before onset the experiment, all ewes were fed flushing diet in August and after breeding they fed on pasture till about 5 weeks prior to lambing. The experiment was conducted from 35-d before parturition (14 d 
for adaptation to dietary treatments and $21 \mathrm{~d}$ for measurements [pre-partum phase]) to day 21 of lactation (post-partum phase). Dietary treatments contained 1) no flaxseed $+20 \%$ dietary RUP (no flaxseed, low RUP [NFLR]); 2) no flaxseed + 40\% dietary RUP (no flaxseed, high RUP [NFHR]); 3) $10 \%$ whole flaxseed $+20 \%$ dietary RUP (whole flaxseed, low RUP [WFLR]); 4) 10\% whole flaxseed + 40\% dietary RUP (whole flaxseed, high RU [WFHR]); 5) 10\% extruded flaxseed + 20\% dietary RUP (extruded flaxseed, low RUP [EFLR]) and 6) 10\% extruded flaxseed $+40 \%$ dietary RUP (extruded flaxseed, high RUP [EFHR]). Ewes were housed in the $1.5 \times 1.5 \mathrm{~m}$ individual tie stalls with rubber mats. The animals had free access to fresh water and feed. Diets were offered as a total mixed ration (TMR) which were formulated based on small ruminant nutrition system (SRNS) [18] to meet the ewe's nutrient requirements [19]. The diets were fed to ewes at 08:00 and 16:00 $\mathrm{h}$ during pre-partum and post-partum periods to ensure about $5 \%$ ort.

To achieve isonitrogenous and isoenergetic diets they were formulated by replacing barley grain with flaxseed and nitrogen (the proportions of RUP) balanced using change in the proportions of soybean meal and urea. The Yasminomax product (46\% CP and 70\% RUP) as a source of RUP was purchased from Sanadam Pars, Tehran, Iran. Ingredients and chemical composition of diets and flaxseed during the transition period are shown in Tables 1 and 2, respectively.

\section{Measurements}

The DM intake and refusals were recorded daily. All ewes were weekly weighted $4 \mathrm{~h}$ before morning feeding. The blood samples were gathered from jugular vein, using heparinized plastic syringes, $3 \mathrm{~h}$ after the morning feeding on days 7 and 14 pre- and post-partum to obtain plasma via centrifugation at $3,000 \times \mathrm{g}$ for $15 \mathrm{~min}$. The plasma was stored at $-20^{\circ} \mathrm{C}$ until later analysis for glucose, $\beta$-hydroxybutyric acid (BHBA), non-esterified fatty acid (NEFA) and urea by commercial kits (Pars Azmon, Tehran, Iran and Randox, Randox Laboratories, Crumlin, UK).

To determine colostrum yield, ewes were milked 1,10 and $18 \mathrm{~h}$ post-parturition and a 50-g samples of colostrum were collected and analyzed for fat and protein contents [20]. The ewes were milked twice a day at 09:00 and17:00 $\mathrm{h}$ and individual yields were recorded at each morning and evening milking. The collected milk samples from each ewe were mixed proportionally based on morning and evening milk yield and then were analyzed for fat and protein by a MilkoScan (TM minor model 78110, Foss Analytical A/S, Hillerød, Denmark) and also milk FAs profile.

\section{Laboratory analysis}

The DM was measured by drying a subsample at $105^{\circ} \mathrm{C}$ (method no. 934.01) in a forced-air oven [21]. The ash (method no. 945.38) and the ether extract (EE, method no. 945.18) contents were determined based on AOAC procedures [21]. The CP content (method no. 997.06) was measured by kjeldahl method (Kjel-Foss, Kjeltec Auto 1030). The acid detergent fiber (ADF) and neutral detergent fiber (NDF) concentrations were measured according to the methods presented by Van Soest et al. [22].

Plasma metabolites were determined by an auto-analyzer (Abbott Alcyon 300, Abbot Diagnostics, Lake Forest, IL, USA). The profile of milk FAs were determined as described by Fougère et al. [23]. Briefly, the incubation of freeze-dried milk samples was conducted with $2 \mathrm{~mL}$ of $0.5 \mathrm{M}$ sodium methoxide in anhydrous methanol and $1 \mathrm{~mL}$ of hexane at $50^{\circ} \mathrm{C}$ for $15 \mathrm{~min}$, and the mixture was cooled. They were then incubated under similar conditions with the addition of $1 \mathrm{~mL}$ of $37 \%$ methanol/hydrochloric acid (95:5 v/v). To extract fatty acid methyl esters (FAME) of the milk samples, $1.5 \mathrm{~mL}$ of hexane and $3 \mathrm{~mL}$ of aqueous $(6 \% \mathrm{w} / \mathrm{v})$ potassium carbonate were added and recovered in the hexanoic phase. One $\mu \mathrm{L}$ of recovered hexane phase was injected into gas chromatography (CP-3800 GC, Varian, Palo Alto, CA, USA) assembled with a flame ionization 
Table 1. Ingredient and chemical composition of diets (\% of DM) fed to Baluchi ewes during the transition period

\begin{tabular}{|c|c|c|c|c|c|c|c|c|c|c|c|c|}
\hline & \multicolumn{6}{|c|}{ Pre-lambing } & \multicolumn{6}{|c|}{ Post-lambing } \\
\hline & \multicolumn{2}{|c|}{ No flaxseed } & \multicolumn{2}{|c|}{$\begin{array}{c}10 \% \\
\text { whole flaxseed }\end{array}$} & \multicolumn{2}{|c|}{$\begin{array}{c}10 \% \\
\text { extruded flaxseed }\end{array}$} & \multicolumn{2}{|c|}{ No flaxseed } & \multicolumn{2}{|c|}{$\begin{array}{c}10 \% \\
\text { whole flaxseed }\end{array}$} & \multicolumn{2}{|c|}{$\begin{array}{c}10 \% \\
\text { extruded flaxseed }\end{array}$} \\
\hline & $\begin{array}{l}20 \% \\
\text { RUP }^{11}\end{array}$ & $\begin{array}{l}40 \% \\
\text { RUP }\end{array}$ & $\begin{array}{l}20 \% \\
\text { RUP }\end{array}$ & $\begin{array}{l}40 \% \\
\text { RUP }\end{array}$ & $\begin{array}{l}20 \% \\
\text { RUP }\end{array}$ & $\begin{array}{l}40 \% \\
\text { RUP }\end{array}$ & $\begin{array}{l}20 \% \\
\text { RUP }\end{array}$ & $\begin{array}{l}40 \% \\
\text { RUP }\end{array}$ & $\begin{array}{l}20 \% \\
\text { RUP }\end{array}$ & $\begin{array}{l}40 \% \\
\text { RUP }\end{array}$ & $\begin{array}{l}20 \% \\
\text { RUP }\end{array}$ & $\begin{array}{l}40 \% \\
\text { RUP }\end{array}$ \\
\hline & (NFLR) & (NFHR) & (WFLR) & (WFHR) & (EFLR) & (EFHR) & (NFLR) & (NFHR) & (WFLR) & (WFHR) & (EFLR) & (EFHR) \\
\hline \multicolumn{13}{|l|}{ Ingredients (\%DM) } \\
\hline Barley grain (grounded) & 15.1 & 15.1 & 5.1 & 5.1 & 5.1 & 5.1 & 27.5 & 27.5 & 7.5 & 17.5 & 7.5 & 17.5 \\
\hline Soybean meal & 5.4 & 3 & 2.3 & - & 2.3 & - & - & 8 & - & 4.5 & - & 4.5 \\
\hline Beet pulp & - & - & 7.7 & 2.3 & 7.7 & 2.3 & - & - & 29.5 & 3.5 & 29.5 & 3.5 \\
\hline Wheat bran & 4.6 & - & - & - & - & - & 19.5 & 5 & - & 5 & - & 5 \\
\hline Yasminomax ${ }^{2)}$ & - & 7.7 & - & 8.4 & - & 8.4 & - & 8.5 & - & 8.5 & - & 8.5 \\
\hline Calcium carbonate & 0.4 & 0.4 & 0.4 & 0.4 & 0.4 & 0.4 & 0.5 & 0.5 & 0.5 & 0.5 & 0.5 & 0.5 \\
\hline Minerals-vitamins ${ }^{3)}$ & 0.4 & 0.4 & 0.4 & 0.4 & 0.4 & 0.4 & 0.5 & 0.5 & 0.5 & 0.5 & 0.5 & 0.5 \\
\hline \multicolumn{13}{|c|}{ Chemical composition (\% in DM) } \\
\hline DM & 31 & 31 & 31 & 31 & 31 & 31 & 45 & 45 & 45 & 45 & 45 & 45 \\
\hline ME (Mcal/kg DM) & 2.2 & 2.2 & 2.2 & 2.2 & 2.2 & 2.2 & 2.3 & 2.3 & 2.4 & 2.5 & 2.4 & 2.5 \\
\hline $\mathrm{CP}$ & 12.2 & 12 & 12.1 & 12.2 & 12.1 & 12.2 & 15.6 & 15.6 & 15.8 & 15.6 & 15.8 & 15.6 \\
\hline NDF & 44.1 & 43.7 & 44.4 & 44.7 & 44.4 & 44.7 & 40.3 & 37.0 & 39.5 & 37.8 & 39.5 & 37.8 \\
\hline $\mathrm{EE}$ & 2.9 & 2.8 & 6 & 6.1 & 6 & 6.1 & 3 & 2.6 & 5.5 & 6 & 5.5 & 6 \\
\hline
\end{tabular}

${ }^{1)}$ Rumen undegradable protein.

${ }^{2)}$ Yasminomax contained 46\% CP, 70\% RUP, 7\% ash, 4\% fat (DM basis).

${ }^{3)}$ Mineral and vitamin mix contained $200 \mathrm{~g} / \mathrm{kg} \mathrm{Ca}, 98 \mathrm{~g} / \mathrm{kg} \mathrm{P}, 21 \mathrm{~g} / \mathrm{kg} \mathrm{Mg}, 44$ g/kg Na, 0.3 g/kg Cu, 2 g/kg Mn, 3 g/kg Fe, 3 g/kg Zn, $0.1 \mathrm{~g} / \mathrm{kg} \mathrm{I,} 0.1 \mathrm{~g} / \mathrm{kg} \mathrm{Co,} 0.001$ g/kg Se, 500,000 IU/ $\mathrm{kg}$ of vitamin A, $100 \mathrm{mg} / \mathrm{kg}$ of vitamin E, $100,000 \mathrm{lU} / \mathrm{kg}$ of vitamin $\mathrm{D}_{3}$, and $400 \mathrm{mg} / \mathrm{kg}$ Antioxidant.

DM, dry matter; RUP, rumen undegradable protein; NFLR, no flaxseed, low RUP; NFHR, no flaxseed, high RUP; WFLR, whole flaxseed, low RUP; WFHR, whole flaxseed, high RU; EFLR, extruded flaxseed, low RUP; EFHR, extruded flaxseed, high RUP; ME, metabolizable energy; CP, crude protein; NDF, neutral detergent fiber; EE, ether extract; RDP, rumen degradable protein.

Table 2. The chemical composition of flaxseed used in transition diets

\begin{tabular}{lc}
\multicolumn{1}{c}{ Composition } & Content \\
\hline DM (\% of fresh weight) & 94.62 \\
Crude protein (\% of DM) & 18.7 \\
Ether extract (\% of DM) & 41.05 \\
Neutral detergent fiber (\% of DM) & 22.21 \\
Acid detergent fiber (\% of DM) & 18.73 \\
Ash (\% of DM) & 2.95 \\
\hline
\end{tabular}

DM, dry matter. 
detector at $260^{\circ} \mathrm{C}$ and a CP-Sil 88 capillary column $(100 \mathrm{~m} \times 0.25 \mathrm{~mm}$ i.d. $\times 0.2 \mu \mathrm{m}$ film thickness; made by Chrompack [Middelburg, The Netherlands], supplied by Varian [Mississauga, ON, Canada]). Helium with a flow rate of $20 \mathrm{~cm} / \mathrm{sec}$ was used as a carrier gas. The FAME profile was determined in a $1-\mu \mathrm{L}$ sample at a $1: 100$ split ratio and $260^{\circ} \mathrm{C}$ temperature of the injector using a temperature program $\left(140^{\circ} \mathrm{C}[5 \mathrm{~min}]\right.$ to $240^{\circ} \mathrm{C}$ at $\left.4{ }^{\circ} \mathrm{C} / \mathrm{min}\right)$. To identify peaks, the retention time was compared with commercial standards that contained mixtures of 37 FAME (18919-1AMP, LR-0565, Sigma, St. Louis, MO, USA; and O5632, Sigma, Steinheim, Germany).

\section{Statistical analysis}

All data were analyzed using the MIXED procedure of SAS Institute [24] for a completely randomized design with a $3 \times 2$ factorial arrangement of treatments. The Duncan's Multiple Range Test was employed to determine means that were significantly different at $p<0.05$. Trends were also considered when $p<0.1$. Data were analyzed using the following statistical model:

$$
Y_{\mathrm{ijk}}=\mu+E_{\mathrm{i}}+\mathrm{F}_{\mathrm{j}}+\mathrm{R}_{\mathrm{k}}+(\mathrm{FR})_{\mathrm{jk}}+\mathrm{e}_{\mathrm{ijk}}
$$

Where, $Y_{\mathrm{ijk}}$ are dependent variables, $\mu$ is the total mean, $E_{\mathrm{i}}$ is random effect of animal, $\mathrm{F}_{\mathrm{i}}$ is fixed effect of flaxseed factor, $R_{j}$ is fixed effect of RUP factor, $(F R)_{i j}$ is interaction effect of flaxseed and RUP, and $\mathrm{e}_{\mathrm{ijk}}$ is random residual error with a mean and variance of 0 and $\sigma 2$, respectively.

\section{RESULTS}

Dry matter intake, body weight changes, colostrum and milk production and composition

As shown in Table 3, the dry matter intake (DMI) of ewes was affected by flaxseed, with a

Table 3. DMI, BW change, yield and composition of colostrum and milk in transition ewes fed two flaxseed types and two RUP levels

\begin{tabular}{|c|c|c|c|c|c|c|c|c|c|c|}
\hline & \multicolumn{6}{|c|}{ Level and type flaxseed } & \multirow{3}{*}{ SEM } & \multirow{2}{*}{\multicolumn{3}{|c|}{$p$-value }} \\
\hline & \multicolumn{2}{|c|}{ No flaxseed } & \multicolumn{2}{|c|}{$\begin{array}{c}10 \% \\
\text { whole flaxseed }\end{array}$} & \multicolumn{2}{|c|}{$\begin{array}{c}10 \% \\
\text { extruded flaxseed }\end{array}$} & & & & \\
\hline & $\begin{array}{l}\text { 20\%RUP } \\
\text { (NFLR) }\end{array}$ & $\begin{array}{l}\text { 40\%RUP } \\
\text { (NFHR) }\end{array}$ & $\begin{array}{c}20 \% R U P \\
\text { (WFLR) }\end{array}$ & $\begin{array}{l}\text { 40\%RUP } \\
\text { (WFHR) }\end{array}$ & $\begin{array}{c}\text { 20\%RUP } \\
\text { (EFLR) }\end{array}$ & $\begin{array}{l}\text { 40\%RUP } \\
\text { (EFHR) }\end{array}$ & & Flax & RUP & $\begin{array}{c}\text { Flax } x \\
\text { RUP }\end{array}$ \\
\hline \multicolumn{11}{|l|}{ Pre-lambing } \\
\hline DMI (kg/day) & 1.07 & 0.95 & 1 & 1.01 & 1.12 & 1.18 & 0.03 & 0.001 & 0.560 & 0.017 \\
\hline BW change $(\mathrm{kg})$ & 6 & 5.45 & 4.65 & 5.6 & 5.56 & 5.95 & 0.37 & 0.600 & 0.901 & 0.650 \\
\hline \multicolumn{11}{|l|}{ Post-lambing } \\
\hline DMI (kg/day) & 1.84 & 1.77 & 1.98 & 1.75 & 1.92 & 1.89 & 0.04 & 0.031 & 0.007 & 0.028 \\
\hline BW change $(\mathrm{kg})$ & -0.83 & -0.02 & 0.32 & 1.58 & 0.70 & 1.28 & 0.84 & 0.271 & 0.055 & 0.781 \\
\hline \multicolumn{11}{|l|}{ Colostrum } \\
\hline Yield (kg) & 1.89 & 1.83 & 1.90 & 1.88 & 2.43 & 2.38 & 0.27 & 0.097 & 0.860 & 0.998 \\
\hline Fat (\%) & 9.6 & 9.3 & 9.2 & 9.9 & 9.5 & 9.9 & 0.78 & 0.950 & 0.670 & 0.800 \\
\hline Protein (\%) & 4.7 & 4.3 & 4.6 & 5.1 & 4.9 & 4.1 & 0.44 & 0.641 & 0.510 & 0.280 \\
\hline \multicolumn{11}{|l|}{ Milk } \\
\hline Yield (kg) & 1.37 & 1.94 & 1.59 & 2.03 & 2.23 & 1.83 & 0.18 & 0.130 & 0.170 & 0.021 \\
\hline Fat (\%) & 6.75 & 4.83 & 5.45 & 5.42 & 5.33 & 4.87 & 0.38 & 0.211 & 0.013 & 0.041 \\
\hline Protein (\%) & 3.33 & 3.51 & 3.43 & 3.53 & 3.43 & 3.54 & 0.05 & 0.410 & 0.002 & 0.661 \\
\hline
\end{tabular}

DMI, dry matter intake; BW, body weight; RUP, rumen undegradable protein; NFLR, no flaxseed, low RUP; NFHR, no flaxseed, high RUP; WFLR, whole flaxseed, low RUP; WFHR, whole flaxseed, high RU; EFLR, extruded flaxseed, low RUP; EFHR, extruded flaxseed, high RUP. 
significant interaction between flaxseed and RUP level at pre- and post-lambing $(p<0.05)$. Increasing RUP caused lower DMI in ewes fed a diet without flaxseed but did not affect DMI in flaxseed fed ewes at prepartum. During pre-lambing, ewes fed a diet containing 10\% extruded flaxseed showed a higher DMI when compared to other groups $(p<0.01)$. However, at postlambing, ewes fed $10 \%$ extruded flaxseed $(p<0.05)$ or $20 \%$ RUP $(p<0.01)$ had significantly higher DMI than those fed no flaxseed or 40\% RUP $(p<0.05)$. At post-lambing, body weight change tended to increase in animals fed the diets containing $40 \%$ RUP $(p<0.1)$ compared to $20 \%$ RUP.

Flaxseed had no significant effect on colostrum and its composition, the colostrum yield tended to increase $(p<0.1)$ in ewes fed the diets containing extruded flaxseed compared to the whole flaxseed or no flaxseed diets (Table 3). Although milk yield was not significantly influenced by flaxseed or RUP, their interaction was significant, and milk yield increased by increasing RUP in ewes fed a diet without flaxseed $(p<0.05)$, whereas it had no effect on ewes fed with whole or extruded flaxseed. Thus, ewes fed with NFHR, WFHR, EFLR, and EFHR produced higher milk compared to NFLR and WFLR $(p<0.05)$. The RUP levels influenced the fat and protein concentrations of milk ( $p<0.05$ and $p<0.01$, respectively), and ewes fed low RUP had more fat percentage but produced lower protein compared to those fed high RUP. There was also a significant interaction between flaxseed and RUP for milk fat percentage $(p<0.05)$.

\section{Blood metabolites}

The serum concentration of NEFA was not affected by the flaxseed or RUP level at pre-lambing (Table 4). However, there was a significant $(p<0.01)$ interaction between flaxseed and RUP for NEFA concentration at post-lambing. As shown in Table 4 , at prepartum, the concentration of BHBA was affected by flaxseed $(p=0.001)$ and RUP level $(p=0.07)$ with a significant interaction effect $(p=0.001)$. In this regard, the serum concentration of BHBA reduced with RUP raising in flaxseed fed ewes; however, a greater BHBA in ewes fed a diet without flaxseed was indicated in the diet with higher RUP level. A converse trend for BHBA was observed postpartum. At the postlambing period, the BHBA concentrations significantly rose $(p<0.01)$ in extruded flaxseed fed ewes compared to whole flaxseed or no flaxseed.

Blood glucose and urea concentrations boosted by increasing RUP at pre- and postpartum

Table 4. Blood metabolites in transition ewes fed two flaxseed types and two RUP levels

\begin{tabular}{|c|c|c|c|c|c|c|c|c|c|c|}
\hline & \multicolumn{6}{|c|}{ Level and type flaxseed } & \multirow{3}{*}{ SEM } & \multirow{2}{*}{\multicolumn{3}{|c|}{$p$-value }} \\
\hline & \multicolumn{2}{|c|}{ No flaxseed } & \multicolumn{2}{|c|}{$\begin{array}{c}10 \% \\
\text { whole flaxseed }\end{array}$} & \multicolumn{2}{|c|}{$\begin{array}{c}10 \% \\
\text { extruded flaxseed }\end{array}$} & & & & \\
\hline & $\begin{array}{l}\text { 20\%RUP } \\
\text { (NFLR) }\end{array}$ & $\begin{array}{l}\text { 40\%RUP } \\
\text { (NFHR) }\end{array}$ & $\begin{array}{l}\text { 20\%RUP } \\
\text { (WFLR) }\end{array}$ & $\begin{array}{l}\text { 40\%RUP } \\
\text { (WFHR) }\end{array}$ & $\begin{array}{l}\text { 20\%RUP } \\
\text { (EFLR) }\end{array}$ & $\begin{array}{l}\text { 40\%RUP } \\
\text { (EFHR) }\end{array}$ & & Flax & RUP & $\begin{array}{l}\text { Flax } x \\
\text { RUP }\end{array}$ \\
\hline \multicolumn{11}{|l|}{ Pre-lambing } \\
\hline $\mathrm{NEFA}(\mathrm{mmol} / \mathrm{L})$ & 0.31 & 0.33 & 0.30 & 0.24 & 0.28 & 0.32 & 0.02 & 0.541 & 0.850 & 0.381 \\
\hline Glucose (mg/dL) & 67.2 & 73.0 & 67.2 & 72.8 & 75.2 & 87.0 & 1.96 & 0.001 & 0.001 & 0.262 \\
\hline Blood urea (mg/dL) & 55.6 & 66.0 & 56.2 & 77.0 & 51.7 & 55.20 & 1.57 & 0.001 & 0.001 & 0.002 \\
\hline \multicolumn{11}{|l|}{ Post-lambing } \\
\hline $\mathrm{NEFA}(\mathrm{mmol} / \mathrm{L})$ & 0.15 & 0.23 & 0.37 & 0.32 & 0.17 & 0.33 & 0.02 & 0.003 & 0.001 & 0.001 \\
\hline $\mathrm{BHBA}(\mathrm{mmol} / \mathrm{L})$ & 0.51 & 0.39 & 0.37 & 0.42 & 0.45 & 0.57 & 0.03 & 0.009 & 0.320 & 0.006 \\
\hline
\end{tabular}

RUP, rumen undegradable protein; NFLR, no flaxseed, low RUP; NFHR, no flaxseed, high RUP; WFLR, whole flaxseed, low RUP; WFHR, whole flaxseed, high RU; EFLR, extruded flaxseed, low RUP; EFHR, extruded flaxseed, high RUP; NEFA, non-esterified fatty acid; BHBA, $\beta$-hydroxybutyric acid. 
$(p<0.01)$. During both lambing periods, the ewes fed extruded flaxseed had a higher glucose concentration than other groups $(p<0.01)$. The serum concentration of blood urea was also affected by flaxseed type at the pre- and post-lambing periods $(p<0.01)$, and higher blood urea concentration was observed in animals fed whole flaxseed based diets than other groups.

The profile of fatty acids in milk fat

The effects of dietary treatments on milk FAs composition are presented in Table 5. In general,

Table 5. The milk fatty acids profile ( $\mathrm{g} / 100 \mathrm{~g}$ of total fatty acids) in the transition ewes fed two flaxseed types and two RUP levels

\begin{tabular}{|c|c|c|c|c|c|c|c|c|c|c|}
\hline & \multicolumn{6}{|c|}{ Level and type flaxseed } & \multirow{3}{*}{ SEM ${ }^{1)}$} & & & \\
\hline & \multicolumn{2}{|c|}{ No flaxseed } & \multicolumn{2}{|c|}{$10 \%$ whole flaxseed } & \multicolumn{2}{|c|}{$10 \%$ extruded flaxseed } & & \multicolumn{3}{|c|}{$p$-value } \\
\hline & $\begin{array}{c}\text { 20\%RUP } \\
\text { (NFLR) }\end{array}$ & $\begin{array}{l}\text { 40\%RUP } \\
\text { (NFHR) }\end{array}$ & $\begin{array}{c}\text { 20\%RUP } \\
\text { (WFLR) }\end{array}$ & $\begin{array}{c}\text { 40\%RUP } \\
\text { (WFHR) }\end{array}$ & $\begin{array}{c}\text { 20\%RUP } \\
\text { (EFLR) }\end{array}$ & $\begin{array}{l}\text { 40\%RUP } \\
\text { (EFHR) }\end{array}$ & & Flax & RUP & $\begin{array}{c}\text { Flax } x \\
\text { RUP }\end{array}$ \\
\hline \multicolumn{11}{|l|}{ Fatty acid } \\
\hline $\mathrm{C} 4: 0$ & 1.41 & 1.55 & 1.87 & 1.88 & 1.61 & 1.94 & 0.15 & 0.69 & 0.70 & 0.94 \\
\hline $\mathrm{C} 6: 0$ & 1.43 & 1.36 & 1.42 & 1.39 & 1.49 & 1.42 & 0.06 & 0.93 & 0.717 & 0.99 \\
\hline $\mathrm{C} 8: 0$ & 1.96 & 1.68 & 1.80 & 2.07 & 1.86 & 1.90 & 0.09 & 0.71 & 0.95 & 0.20 \\
\hline C10:0 & 5.96 & 5.78 & 5.7 & 5.88 & 5.86 & 5.39 & 0.18 & 0.91 & 0.75 & 0.86 \\
\hline $\mathrm{C} 11: 0$ & 0.16 & 0.20 & 0.18 & 0.17 & 0.18 & 0.15 & 0.10 & 0.82 & 0.97 & 0.42 \\
\hline $\mathrm{C} 12: 0$ & 3.42 & 3.15 & 3.4 & 3.92 & 3.12 & 3.74 & 0.12 & 0.41 & 0.23 & 0.25 \\
\hline $\mathrm{C} 13: 0$ & 0.05 & 0.04 & 0.03 & 0.05 & 0.09 & 0.04 & 0.006 & 0.001 & 0.001 & 0.001 \\
\hline C14:0 & 10.56 & 10.84 & 9.01 & 9.04 & 9.13 & 9.31 & 0.25 & 0.007 & 0.59 & 0.94 \\
\hline C14:1 & 0.12 & 0.13 & 0.19 & 0.22 & 0.20 & 0.25 & 0.02 & 0.03 & 0.26 & 0.75 \\
\hline C15:0 & 0.67 & 0.75 & 0.99 & 1.07 & 0.66 & 0.82 & 0.006 & 0.084 & 0.03 & 0.59 \\
\hline C16:0 & 27.24 & 27.19 & 26.97 & 24.30 & 23.53 & 23.40 & 0.69 & 0.11 & 0.47 & 0.63 \\
\hline C16:1 & 0.66 & 0.53 & 0.89 & 0.96 & 1.04 & 1.06 & 0.08 & 0.002 & 0.74 & 0.17 \\
\hline C17:0 & 1.05 & 0.88 & 0.68 & 0.75 & 0.79 & 0.58 & 0.05 & 0.03 & 0.05 & 0.06 \\
\hline C17:1 & 0.58 & 0.44 & 0.20 & 0.21 & 0.25 & 0.22 & 0.04 & 0.001 & 0.08 & 0.13 \\
\hline C18:0 & 13.87 & 13.48 & 13.72 & 14.13 & 13.59 & 13.21 & 0.30 & 0.86 & 0.88 & 0.89 \\
\hline C18:1n9t & 2.74 & 3.16 & 3.68 & 3.84 & 3.00 & 4.73 & 0.25 & 0.21 & 0.10 & 0.31 \\
\hline cis-9C18:1, oleic acid & 24.06 & 24.25 & 23.87 & 21.61 & 25.10 & 25.23 & 0.66 & 0.47 & 0.68 & 0.76 \\
\hline trans -9 trans- $12 \mathrm{C} 18: 2$ & 0.27 & 0.34 & 0.33 & 0.36 & 0.35 & 0.25 & 0.03 & 0.82 & 0.98 & 0.61 \\
\hline C18:2 n6, linoleic acid & 1.33 & 1.87 & 2.55 & 2.71 & 2.85 & 2.99 & 0.19 & 0.008 & 0.11 & 0.51 \\
\hline C18:3n3, linolenic acid & 0.52 & 0.59 & 1.02 & 1.32 & 1.79 & 1.99 & 0.18 & 0.01 & 0.28 & 0.73 \\
\hline $\mathrm{C} 20: 0$ & 0.29 & 0.31 & 0.25 & 0.28 & 0.15 & 0.17 & 0.02 & 0.006 & 0.28 & 0.97 \\
\hline $\mathrm{C} 21: 0$ & 1.52 & 1.25 & 1.09 & 0.98 & 0.22 & 0.17 & 0.16 & 0.001 & 0.28 & 0.75 \\
\hline $\mathrm{C} 22: 0$ & 0.11 & 0.17 & 0.36 & 0.16 & 0.15 & 0.13 & 0.03 & 0.003 & 0.03 & 0.003 \\
\hline $\mathrm{C} 20: 4 \mathrm{n} 6$ & 0.25 & 0.12 & 0.11 & 0.16 & 0.16 & 0.19 & 0.01 & 0.02 & 0.14 & 0.001 \\
\hline Short-chain fatty acids & 14.39 & 13.76 & 14.41 & 15.36 & 14.22 & 13.89 & 0.43 & 0.74 & 0.99 & 0.79 \\
\hline Medium-chain fatty acids & 39.26 & 39.44 & 38.05 & 35.60 & 34.55 & 34.85 & 0.80 & 0.09 & 0.66 & 0.68 \\
\hline Long-chain fatty acids & 46.59 & 46.86 & 47.87 & 46.51 & 48.40 & 49.85 & 0.81 & 0.59 & 0.95 & 0.84 \\
\hline Polyunsaturated fatty acids & 2.37 & 2.92 & 4.02 & 4.55 & 5.14 & 5.42 & 0.35 & 0.001 & 0.19 & 0.92 \\
\hline Monounsaturated fatty acids & 29.68 & 29.76 & 29.93 & 27.82 & 29.81 & 31.66 & 0.54 & 0.47 & 0.96 & 0.43 \\
\hline Saturated fatty acids & 69.70 & 68.63 & 67.47 & 66.07 & 62.44 & 61.67 & 1.10 & 0.01 & 0.45 & 0.98 \\
\hline
\end{tabular}

short-chain fatty acids (C4:0 to C13:0, SCFA); medium-chain fatty acids (C14:0 to C16:1, MCFA); long-chain fatty acids (> C17, LCFA); polyunsaturated fatty acids (trans-9 trans-12 C18:2, C18:2 n6, C18:3n3, C20:4n6, PUFA); monounsaturated fatty acids (C14:1, C16:1, C17:1,C18:1n9t, cis-9 C18:1, C21:0, MUFA); saturated fatty acids (C4:0, C6:0, C8:0, C10:0, C11:0, C12:0, C13:0, C14:0, C15:0, C16:0, C17:0, C18:0, C20:0, C21:0, C22:0, SFA).

RUP, rumen undegradable protein; NFLR, no flaxseed, low RUP; NFHR, no flaxseed, high RUP; WFLR, whole flaxseed, low RUP; WFHR, whole flaxseed, high RU; EFLR, extruded flaxseed, low RUP; EFHR, extruded flaxseed, high RUP. 
linolenic acid (c18:3n3) - linoleic acid(c18:2n6)

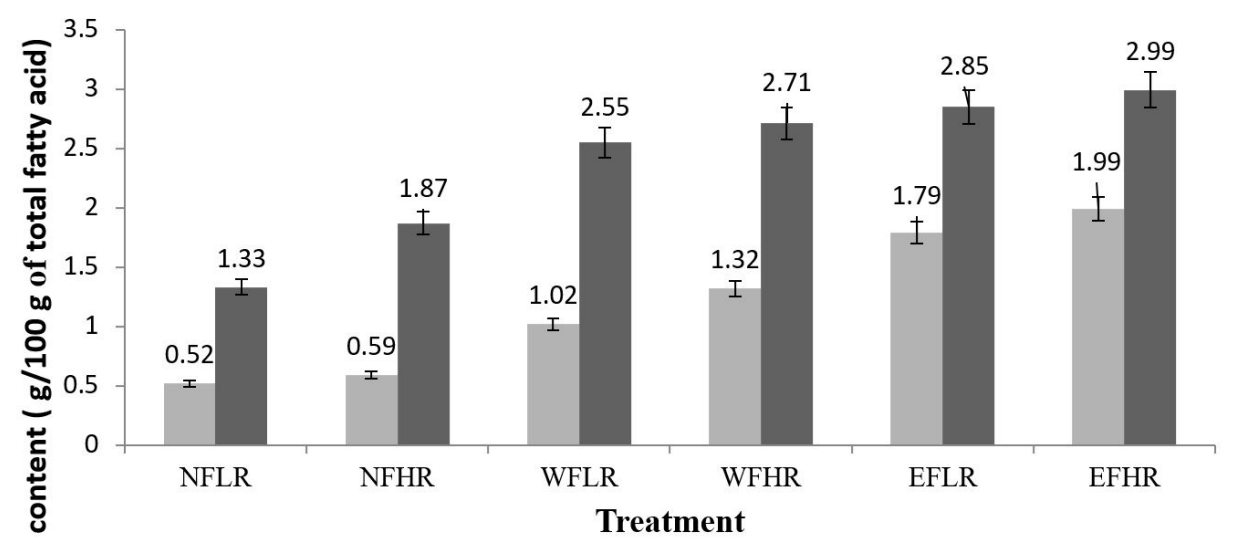

Fig. 1. Linolenic (C18:3n3) and linoleic (C18:2n6) acids concentrations of milk in transition ewes fed two flaxseed types and two RUP levels. Treatment were: NFLR: no flaxseed diet $+20 \%$ dietary RUP, NFHR: no flaxseed diet $+40 \%$ dietary RUP, WFLR: $10 \%$ whole flaxseed diet $+20 \%$ dietary RUP, WFHR: $10 \%$ whole flaxseed diet $+40 \%$ dietary RUP, EFLR: $10 \%$ extruded flaxseed diet $+20 \%$ dietary RUP and EFHR: $10 \%$ extruded flaxseed diet $+40 \%$ dietary RUP. RUP, rumen undegradable protein.

most FA was affected by flaxseed. The flaxseed supplementation and also RUP level did not significantly affect $\mathrm{C} 4: 0$ to $\mathrm{C} 12: 0$ percentages. Higher $\mathrm{C} 13: 0$ was detected in the ewes fed EFLR when compared to other treatments $(p<0.05)$. Animals fed the flaxseed diets produced milk containing a lower amount of C14:0, C17:0, C17:1, C20:0, and C21:0 than those on the no flaxseed diets, regardless of RUP level ( $p<0.05)$. However, C14:1, C16:1, and C18:2 (linoleic acid) significantly increased in ewes fed flaxseed $(p<0.05, p<0.01$ and $p<0.01$, respectively). The highest concentration of $\mathrm{C} 18: 3$ ( $\alpha$-linolenic acid) was observed in milk fat of ewes fed extruded flaxseed compared to the other groups, although the ewes fed with whole flaxseed exhibited higher C18:3 than control group $(p<0.05)$ (Fig. 1). With the exception of C13:0, C17:0, and C22:0, other milk FA were not affected by RUP level. Furthermore, a significant interaction between flaxseed and RUP level was observed for C13:0 and C22:0 $(p<0.01)$.

Short and long-chain FA and also monounsaturated FA were not influenced by flaxseed or RUP level, whereas a trend for a lower amount of medium-chain FA was found in extruded flaxseed fed animals compared to those fed a diet without flaxseed $(p=0.09)$. Feeding ewes with both types of flaxseed significantly increased PUFA concentrations of milk $(p<0.01)$, and this considerably indicated in ewes fed extruded flaxseed. Taken as a whole, saturated FA, which makes up the principal group, was significantly affected by flaxseed $(p<0.05)$, and the ewes fed extruded flaxseed indicated a lower concentration of SFA compared to whole, or no flaxseed fed ewes.

\section{DISCUSSION}

Feed intake, changes in body weight, colostrum and milk yields and their compositions

During pre- and post-lambing, the ewes fed the diet containing 10\% extruded flaxseed showed higher DMI than those fed the control diet. In agreement with our results, the inclusion of low to moderate levels of flaxseed, either as whole or extruded (up to 10\% of diet DM), increased [6,25 (at postpartum)] or did not affect DMI [7,25 (at prepartum)] in dairy cows and goats, whereas high inclusion levels (21\% of diet DM) decreased DMI of cows [26]. This discrepancy among different 
studies could be due to different amounts and types of supplemented oilseeds and could be due to their palatability [25]. In general, it was reported that high FA intake could directly suppress DMI due to its inhibitory effect on rumen motility [27] when total fat concentration is higher than $6 \%$ of the DM [28].

Reducing DMI by rising the RUP level in the postpartum period in the present study was consistent to the findings of Rehman et al. [13], who reported that the DMI of cows significantly decreased by increasing of RUP level from 30\% to 60\%. This reduction could be attributed to the presence of less fermentable protein and the subsequent decline in the ruminal ammonia nitrogen, which would reduce the growth rate of ruminal microorganisms, thus diminishing the nutrient digestibility and DMI [29]. Similarly, Hartwell et al. [30] observed that prepartum DMI was not affected by RUP level, while postpartum intake decreased in high RUP diet compared to low RUP diet. However, they indicated that negative effects for postpartum intake following feeding excess protein during late gestation were not a result of rumen degradable protein (RDP) deficiency as they provided similar $\mathrm{RDP}$ (but different $\mathrm{CP}$ content) for all treatments.

A tendency for greater colostrum production $(p<0.1)$ in extruded flaxseed fed ewes might be related to higher DMI. Consistent to our results, the inclusion of fish oil as a source of n-3 PUFA did not affect the main constituent of goat's colostrum [31]. In contrast, increasing the feeding level of fish oil up to $40 \mathrm{~g} / \mathrm{d}$ led to a linear decline in ewes' total colostrum output [32]. Supplementation of the ewes' diets with digestible undegradable protein (DUP) in the late pregnancy resulted in a higher colostrum yield and yields of components (protein, fat, and solid non-fat contents) within $24 \mathrm{~h}$ of lambing [15]. However, in another study, Annett et al. [20] found that the negative effect of fish oil on colostrum secretion was alleviated by supplying additional DUP, suggesting the responses to elevated DUP is dependent on metabolizable energy (ME) intake.

In no flaxseed and whole flaxseed diets, increasing RUP level led to numerically increase ( $p$ > 0.05 ) in the milk production by $41.6 \%$ and $27.7 \%$, respectively, but extruded flaxseed diets lead to a significant interaction between flaxseed and RUP level which was higher in ewes fed on EFLR compared to WFLR and NFLR. Do Perdo et al. [33] reported that despite the positive effects of feeding flaxseed or linola (4.8\%) on DMI and energy balance, milk yield was higher for cows fed Megalc (1.1\% of diet DM) which disagrees with the results of Petit [34], who found no difference in milk yield when cows were fed with whole flaxseed (13.9\% of diet DM). Conversely, Zachut et al. [24] observed higher milk yield in cows fed 10.7\% extruded flaxseed compared to control. Therefore, responses to flaxseed supplementation are still controversial and can be associated to the amounts and forms of supplemental flaxseed or to interactions with other diet components [25].

In contrast to our findings, supplementation of dairy cow's diet with whole or micronized flaxseeds reduced milk protein [35] or fat contents [36]. Morsy et al. [37] reported that a decrease in milk fat content following the inclusion of flaxseed oil was related to changes in microbial activity and biohydrogenation of PUFA, leading to the accumulation of trans-10 C18:1. The latter has a crucial inhibitory role in short- and medium-chain FA synthesis in the udder's epithelial cells, hence reducing milk fat [36]. Furthermore, oilseeds are typically rich in long-chain unsaturated FA, which can depress milk fat content through their adverse impacts on fiber digestion and subsequently ruminal acetate concentration [38].

Compared to 20\% RUP, ewes consuming 40\% RUP produced more milk protein concentration. It was reported that supplementation of ruminant diets with RUP could enhance the flow of nitrogen and essential amino acids to duodenum; hence, increase the milk yield and milk protein concentration in cattle and sheep [13,39]. However, Mikolayunas-Sandrock et al. [40] reported a $14 \%$ increase in milk yield and milk fat as well as a $15 \%$ increase in milk protein yield when dairy ewes were fed the diets containing high RUP compared to the group receiving lower RUP, without 
any significant changes in milk fat or protein percentages.

\section{Blood metabolites}

Almost all measured blood metabolites were within the range reported for sheep [41,42]. Except for NEFA at prepartum, other blood parameters were significantly affected by flaxseed, RUP, or their interactions. Petit [27] found no changes in NEFA, BHBA, and glucose concentrations for cows fed with different levels of whole flaxseed. He noted that this lack of effect was related to a similar energy balance among treatments. The higher concentration of BHBA in ewes fed NFHR could be ascribed by lower prepartum energy intake which could lead to moderate ketosis ( 0.8 and $1.6 \mathrm{mmol} / \mathrm{L}$ ), although their blood glucose concentration was within the normal range of 31 to 81 $\mathrm{mg} / \mathrm{dL}$ reported by Christian and Pugh [43]. It has been stated that, in contrast to dairy cows, an increased concentration of ketone bodies is not always accompanied by glucose deficiencies in ewes [44]. However, at post lambing, concentrations of BHBA in NFLR fed ewes were back to normal range. An increase in serum concentration of glucose and the significant reduction of serum BHBA in ewes fed WFHR and EFHR at the pre-lambing period indicated the improved energy status of body compared to other treatments.

The serum NEFA concentration is considered an index for adipose fat mobilization [45]. Increased NEFA concentrations postpartum in ewes fed whole or extruded flaxseed compared to the control might indicate the breakdown of fat as a result of increased energy demand, suggesting that the ewes were in negative energy balance due to the increased nutrient demands for milk production. However, NEFA concentration may progressively fall due to increased DMI and energy balance [46]. Bertics et al. [47] reported that DMI is inversely related to concentrations of NEFA and BHBA in plasma which disagrees with the data from the current study. Kholif et al. [48] reported that plasma concentrations of NEFA were increased with feeding $20 \mathrm{~mL}$ flaxseed or soybean oil; however, in another study, the inclusion of $50 \mathrm{~g}$ crushed flaxseed or $20 \mathrm{~mL}$ flaxseed oil did not affect NEFA concentration in goats [7]. This discrepancy may be due to providing additional energy density required for milk production.

The diets containing extruded flaxseed and also 40\% RUP elevated the serum glucose concentration in ewes at pre- and post-lambing periods which is in agreement with JahaniMoghadam et al. [49] and Kholif et al. [48], who reported higher serum glucose concentration by adding flaxseed or feeding diets containing n3-PUFA. This increment might be due to the improvement in nutrient digestion and ruminal fermentation, as well as improved production of propionate $[37,48]$. Furthermore, it seems that blood glucose concentration is related to changes in DMI as well as the effect of supplemented extruded flaxseed as a source of PUFA on glucose metabolism. Qin et al. [50] reported that the increase in glucose concentrations in fat supplemented groups might be as a consequence of higher somatotropin concentrations, as somatotropin was found to stimulate hepatic gluconeogenesis to supply the energy demand of the lactating mammary gland [51]. Moreover, increased RUP resulted in higher serum glucose content through gluconeogenesis from excess amino acids other than its utilization towards mammary protein synthesis. Therefore, it may explain the increase of serum concentration of glucose caused by increasing RUP level to $40 \%$ in treatments containing extruded flaxseed. These findings are in agreement with those presented by Milis et al. [52] and Amanlou et al. [15].

Plasma urea is an indicator of protein supply or protein utilization that is influenced by the animals' nutritional status [53]. Reduction in blood urea concentration in ewes fed extruded flaxseed compared to those fed with whole flaxseed or without flaxseed may probably be explained by the effectiveness of oilseeds in controlling the ruminal protozoa population and improving the efficiency of dietary protein intake [54]. Furthermore, Johnson et al. [55] stated that feeding 
cows with oilseeds increased plasma urea levels due to increased ruminal nitrogen absorption. The significant increase in serum blood urea concentration with a higher RUP level of diets to $40 \%$ was somewhat unexpected. However, this finding is in agreement with Amanlou et al. [15], who reported that elevating DUP and dietary protein simultaneously resulted in increased serum blood urea of sheep.

\section{Fatty acids profile of the milk fat}

It has been well documented that diet strongly affects both milk fat content and milk FA profile [56]. Similar to our results, Zachut et al. [24] and Neveu et al. [6] observed that the inclusion of flaxseed did not affect the short-chain FA (C4 to C10) content of cow's milk fat. In another study, Glasser et al. [57] reported that oilseeds rich in C18:3 like flaxseed had lower inhibitory effects on de novo short-chain FA synthesis compared to oilseeds rich in C18:2. The abundance of unsaturated FAs, especially C18:3, would explain the results obtained in whole or extruded flaxseed diets. The intermediates of these unsaturated FA which are produced during biohydrogenation in the rumen, can inhibit de novo FA synthesis in the mammary gland and would cause a relative reduction in short and medium-chain FA [56], as seen in Table 5. In the current study, a decrease in odd and branched-chain FA (C15:0 and C17:0) following the inclusion of extruded or whole flaxseed is consistent to Isenberg et al. [58]. This reduction could be due to the variation in the rumen bacterial population since most of these FA derived from bacteria leaving the rumen [59].

The higher concentrations of $\mathrm{C} 14: 1$ and $\mathrm{C} 16: 1$ in milk fat along with higher $\Delta^{9}$-desaturation indexes of $\mathrm{C} 14$ and $\mathrm{C} 16$ (data not shown) in ewes fed extruded and/or whole flaxseed diets than the control group suggested an increase in $\Delta^{9}$-desaturase activity. However, Correddu et al. [60] reported that despite increasing the concentrations of $\mathrm{C} 14: 1, \mathrm{C} 16: 1$, and $\mathrm{C} 18: 1$ with the inclusion of grape seed and linseed in the diet of dairy sheep, the desaturase indexes did not follow the same trend, indicating the increase of these unsaturated FA were not related to an increase in $\Delta^{9}$ desaturase activity.

An increase in ewes' milk $\alpha$-linolenic acid in the diets containing flaxseed agreed with previous studies that used whole or ground flaxseed [5], extruded flaxseed [6], and crushed flaxseed [7]. These elevated effects could simply be a consequence of the direct incorporation of these FA from diet to the mammary gland. Similar to our results, Maamouri et al. [9] reported an increase of $21 \%$ of total FA of $\alpha$-linolenic acid in the diets supplemented with extruded linseed compared to the whole one. Kennelly [61] and Neveu et al. [6] reported that extrusion might denature the protein matrix around the fat droplet, hence protect FAs from ruminal biohydrogenation. However, more recently, Maamouri et al. [9] stated that extrusion might lead to the partial release of the oil due to reduction in the protective effect of oilseeds proteins. This free oil then could interfere with microorganisms responsible for biohydrogenation, thus increase trans-intermediates. Although we could not measure all trans-FAs due to technical limitation, similar concentrations of trans -9 C18:1 and trans- 9 trans -12 C18:2 and also more PUFA in milk fat of extruded compared to whole flaxseed fed ewes might indicate the lack of effect of oil on ruminal biohydrogenation.

Decreases in saturated FA in ewes fed extruded flaxseed are in agreement with most experiments on oil and/or oilseeds in ewes [55,62] and cows [6, 24]. Kholif et al. [7] reported that lower total SFA content in animals fed with a diet containing PUFA-rich oil sources was justified by the inhibitory effect of PUFA on de novo FAs synthesis. This increment in PUFA, along with decreased in SFA of milk fat are beneficial in human health in terms of lowering total and low-density lipoprotein cholesterol [63]. 


\section{CONCLUSION}

The results indicated that the supplementation of ewe's diets with flaxseed (especially the extruded form) during the transition period increased DMI and colostrums compared to diets without flaxseed. However, the advantage of increasing RUP level was to improved milk protein percentage along with higher blood glucose concentration, although ewes fed low RUP had normal glucose contents. Blood parameters varied extensively among treatments due to significant interaction between flaxseed and RUP. The concentrations of linoleic, linolenic, and PUFA were significantly increased about twofold by the inclusion of flaxseed in the diet. In general, it can be concluded that using $10 \%$ extruded flaxseed compared to a control diet in transition dairy sheep feeding had beneficial effects on colostrum yield and insignificant but considerable amount of milk production (1.66 vs. 2.03) and also favorable modification of milk FA profile. However, due to similar performance responses to RUP level and economic point of view, it is recommended to use $20 \%$ RUP in both pre- and post-lambing.

\section{REFRENCES}

1. Dawson LER, Carson AF, Kilpatrick DJ. The effect of digestible undegradable protein concentration of concentrates and protein source offered to ewes in late pregnancy on colostrum production and lamb performance. Anim Feed Sci Technol. 1999;82:21-36. https://doi. org/10.1016/S0377-8401(99)00101-7

2. Petit HV. Review: feed intake, milk production and milk composition of dairy cows fed flaxseed. Can J Anim Sci. 2010;90:115-27. https://doi.org/10.4141/CJAS09040

3. Petit HV, Ivan M, Mir PS. Effects of flaxseed on protein requirements and $\mathrm{N}$ excretion of dairy cows fed diets with two protein concentrations. J Dairy Sci. 2005;88:1755-64. https://doi. org/10.3168/jds. S0022-0302(05)72850-2

4. Petit HV, Benchaar C. Milk production, milk composition, blood composition and conception rate of transition dairy cows fed different profiles of fatty acids. Can J Anim Sci. 2007;87:591600. https://doi.org/10.4141/CJAS07027

5. Petit HV, Côrtes C. Milk production and composition, milk fatty acid profile, and blood composition of dairy cows fed whole or ground flaxseed in the first half of lactation. J Anim Feed Sci Technol. 2010;158:36-43. https://doi.org/10.1016/j.anifeedsci.2010.03.013

6. Neveu C, Baurhoo B, Mustafa A. Effect of feeding extruded flaxseed with different grains on the performance of dairy cows and milk fatty acid profile. J Dairy Sci. 2014;97:1543-51. https:// doi.org/10.3168/jds.2013-6728

7. Kholif AE, Morsy TA, Abdo MM. Crushed flaxseed versus flaxseed oil in the diets of Nubian goats: effect on feed intake, digestion, ruminal fermentation, blood chemistry, milk production, milk composition and milk fatty acid profile. J Anim Feed Sci Technol. 2018;244:66-75. https://doi.org/10.1016/j.anifeedsci.2018.08.003

8. Zhang RH, Mustafa AF, Zhao X. Effects of feeding oilseeds rich in linoleic and linolenic fatty acids to lactating ewes on cheese yield and on fatty acid composition of milk and cheese. J Anim Feed Sci Technol. 2006;127:220-33. https://doi.org/10.1016/j.anifeedsci.2005.09.001

9. Maamouri O, Mahouachi M, Kraiem K, Atti N. Milk production, composition and milk fatty acid profile from grazing ewes fed diets supplemented with Acacia cyanophylla leaves as tannins source and whole or extruded linseed. Livest Sci. 2019;227:120-7. https://doi.org/10.1016/ j.livsci.2019.06.024

10. Shingfield KJ, Bonnet M, Scollan ND. Recent developments in altering the fatty acid com- 
position of ruminant-derived foods. Animal. 2013;7:132-62. https://doi.org/10.1017/ S1751731112001681

11. Wright T, McBride B, Holub B. Docosahexaenoic acid-enriched milk. World Rev Nutr Diet. 1998;83:160-5. https://doi.org/10.1159/000059660

12. Dilzer A, Park Y. Implication of conjugated linoleic acid (CLA) in human health. Crit Rev Food Sci Nutr. 2012;52:488-513. https://doi.org/10.1080/10408398.2010.501409

13. Rehman A, Arif M, Saeed M, Manan A, Al-Sagheer A, EL-Hack ME, et al. Nutrient digestibility, nitrogen excretion, and milk production of mid-lactation Jersey $\times$ Friesian cows fed diets containing different proportions of rumen-undegradable protein. An Acad Bras Ciênc. 2020;92. https://doi.org/10.1590/0001-3765202020180787

14. Mir PS, Mears GJ, Okine EK, Entz T, Ross CM, Husar SD, et al. Effects of increasing dietary grain on viscosity of duodenal digesta and plasma hormone, glucose and amino acid concentrations in steers. Can J Anim Sci. 2000;80:703-12. https://doi.org/10.4141/A99-119

15. Amanlou H, Karimi A, Mahjoubi E, Milis C. Effects of supplementation with digestible undegradable protein in late pregnancy on ewe colostrums production and lamb output to weaning. J Anim Physiol Anim Nutr. 2011;95:616-22. https://doi.org/10.1111/j.1439-0396.2010.01092.x

16. Binns SH, Cox IJ, Rizvi S, Green LE. Risk factors for lamb mortality on UK sheep farms. Prev Vet Med. 2002;52:287-303. https://doi.org/10.1016/s0167-5877(01)00255-0

17. Iranian Council of Animal Care. Guide to the care and use of experimental animals. Vol 1. Isfahan, Iran: Isfahan University of Technology; 1995.

18. Tedeschi LO, Cannas A, Fox DG. A nutrition mathematical model to account for dietary supply and requirements of energy and other nutrients for domesticated small ruminants: the development and evaluation of the small ruminant nutrition system. Small Rum Res. 2010;89:174-84. https://doi.org/10.1016/j.smallrumres.2009.12.041

19. National Research Council [NRC]. Nutrient requirements of small ruminants: sheep, goats, cervids, and new world camelids. Washington, DC: The National Academies Press; 2007.

20. Annett RW, Carson AF, Dawson LER. Effects of digestible undegradable protein (DUP) supply and fish oil supplementation of ewes during late pregnancy on colostrum production and lamb output. J Anim Feed Sci Technol. 2008;146:270-88. https://doi.org/10.1016/j.anifeedsci.2008.01.013

21. AOAC [Association of Official Analytical Chemists] International. Official methods of analysis of AOAC International. 19th ed. Gaithersburg, MD: AOAC International; 2012.

22. Van Soest PJ, Robertson JB, Lewis BA. Methods for dietary fiber, neutral detergent fiber, and nonstarch polysaccharides in relation to animal nutrition. J Dairy Sci. 1991;74:3583-97. https://doi.org/10.3168/jds.S0022-0302(91)78551-2

23. Fougère $H$, Delavaud $C$, Bernard L. Diets supplemented with starch and corn oil, marine algae, or hydrogenated palm oil differentially modulate milk fat secretion and composition in cows and goats: a comparative study. J Dairy Sci. 2018;101:8429-45. https://doi.org/10.3168/ jds.2018-14483

24. SAS, 2003. SAS user's guide: Statistics. Version 9.1. SAS Institute Inc., Cary, North Carolina. USA.

25. Zachut M, Arieli A, Lehrer H, Livshitz L, Yakoby S, Moallem U. Effects of increased supplementation of n-3 fatty acids to transition dairy cows on performance and fatty acids profile in plasma, adipose tissue and milk fat. J Dairy Sci. 2010;93:5877-89. https://doi.org/10.3168/ jds.2010-3427

26. Chilliard Y, Martin C, Rouel J, Doreau M. Milk fatty acids in dairy cows fed whole crude linseed, extruded linseed, or linseed oil, and their relationship with methane output. J Dairy Sci. 
2009;92:5199-211. https://doi.org/10.3168/jds.2009-2375

27. Chilliard Y. Dietary fat and adipose tissue metabolism in ruminants, pigs, and rodents: a review. J Dairy Sci. 1993;76:3897-931. https://doi.org/10.3168/jds.S0022-0302(93)77730-9

28. Petit HV. Digestion, milk production, milk composition, and blood composition of dairy cows fed whole flaxseed. J Dairy Sci. 2002;85:1482-90. https://doi.org/10.3168/jds.S00220302(02)74217-3

29. Tufarelli V, Dario M, Laudadio V. Influence of dietary nitrogen sources with different ruminal degradability on growth performance of Comisana ewe lambs. Small Rum Res. 2009;81:132-6. https://doi.org/10.1016/j.smallrumres.2008.12.014

30. Hartwell JR, Cecava MJ, Donkin SS. Impact of dietary rumen undegradable protein and rumen-protected choline on intake, peripartum liver triacylglyceride, plasma metabolites and milk production in transition dairy cows. J Dairy Sci. 2000;83:2907-17. https://doi.org/10.3168/jds. S0022-0302(00)75191-5

31. Cattaneo D, Dell'Orto V, Varisco G, Agazzi A, Savoini G. Enrichment in n- 3 fatty acids of goat's colostrum and milk by maternal fish oil supplementation. Small Rum Res. 2006;64:22-9. https://doi.org/10.1016/j.smallrumres.2005.03.013

32. Annett RW, Dawson LER, Edgar H, Carson AF. Effects of source and level of fish oil supplementation in late pregnancy on feed intake, colostrum production and lamb output of ewes. J Anim Feed Sci Technol. 2009;154:169-82. https://doi.org/10.1016/j.anifeedsci.2009.09.002

33. Do Prado RM, Palin MF, Do Prado IN, Dos Santos GT, Benchaar C, Petit HV. Milk yield, milk composition, and hepatic lipid metabolism in transition dairy cows fed flaxseed or linola. J Dairy Sci. 2016;99:8831-46. https://doi.org/10.3168/jds.2016-11003

34. Petit HV. Milk production and composition, milk fatty acid profile, and blood composition of dairy cows fed different proportions of whole flaxseed in the first half of lactation.J Anim Feed Sci Technol. 2015;205:23-30. https://doi.org/10.1016/j.anifeedsci.2015.04.009

35. Mustafa AF, Gonthier C, Ouellet DR. Effects of extrusion of flaxseed on ruminal and postruminal nutrient digestibilities. Arch Anim Nutr. 2003;57:455-63. https://doi. org/10.1080/0003942032000161036

36. Hurtaud C, Faucon F, Couvreur S, Peyraud JL. Linear relationship between increasing amounts of extruded linseed in dairy cow diet and milk fatty acid composition and butter properties. J Dairy Sci. 2010;93:1429-43. https://doi.org/10.3168/jds.2009-2839

37. Morsy TA, Kholif SM, Kholif AE, Matloup OH, Salem AZM, Abu Elella A. Influence of sunflower whole seeds or oil on ruminal fermentation, milk production, composition, and fatty acid profile in lactating goats. Asian-Australas J Anim Sci.2015;28:1116-22. https://doi. org/10.5713/ajas.14.0850

38. Onetti SG, Shaver RD, McGuire MA, Grummer RR. Effect of type and level of dietary fat on rumen fermentation and performance of dairy cows fed corn silage-based diets.J Dairy Sci. 2001;84:2751-9. https://doi.org/10.3168/jds.S0022-0302(01)74729-7

39. Volden H. Effects of level of feeding and ruminally undegraded protein on ruminal bacterial protein synthesis, escape of dietary protein intestinal amino acid profile, and performance of dairy cows. J Anim Sci. 1999;77:1905-18. https://doi.org/10.2527/1999.7771905x

40. Mikolayunas-Sandrock C, Armentano LE, Thomas DL, Berger YM. Effect of protein degradability on milk production of dairy ewes. J Dairy Sci. 2009;92:4507-13. https://doi. org/10.3168/jds.2008-1983

41. Merck Veterinary Manual. Serum biochemical reference ranges [Internet]. 2018 [cited 2020 Jan 1]. https://www.msdvetmanual.com/special-subjects/reference-guides/serum-biochemical-reference-ranges 
42. Pichler M, Damberger A, Schwendenwein I, Gasteiner J, Drillich M, Iwersen M. Thresholds of whole-blood $\beta$-hydroxybutyrate and glucose concentrations measured with an electronic hand-held device to identify ovine hyperketonemia.J Dairy Sci. 2014;97:1388-99. https://doi. org/10.3168/jds.2013-7169

43. Christian JA, Pugh DG. Reference intervals and conversions. In: Pugh DB, Baird AN, editors. Sheep and goat medicine. Maryland Heights, MO: WB Saunders; 2012. p. 596-600.

44. Rook JS. Pregnancy toxemia of ewes, does, and beef cows. Vet Clin North Am Food Anim Pract. 2000;16:293-317. https://doi.org/10.1016/S0749-0720(15)30107-9

45. Ingvartsen KL, Andersen JB. Integration of metabolism and intake regulation: a review focusing on periparturient animals. J Dairy Sci. 2000;83:1573-97. https://doi.org/10.3168/jds. S0022-0302(00)75029-6

46. Drackley JK. Biology of dairy cows during the transition period: the final frontier. J Dairy Sci. 1999;82:2259-73. https://doi.org/10.3168/jds.S0022-0302(99)75474-3

47. Bertics SJ, Grummer RR, Cadorniga-Valino C, Stoddard EE. Effect of prepartum dry matter intake on liver triglyceride concentration and early lactation. J Dairy Sci. 1992;75:1914-22. https://doi.org/10.3168/jds.S0022-0302(92)77951-X

48. Kholif AE, Morsy TA, Abd El Tawab AM, Anele UY, Galyean ML. Effect of supplementing diets of Anglo-Nubian goats with soybean and flaxseed oils on lactational performance.J Agric Food Chem. 2016;64:6163-70. https://doi.org/10.1021/acs.jafc.6b02625

49. Jahani-Moghadam M, Mahjoubi E, Dirandeh E. Effect of linseed feeding on blood metabolites, incidence of cystic follicles, and productive and reproductive performance in fresh Holstein dairy cows.J Dairy sci. 2015;98:1828-35. https://doi.org/10.3168/jds.2014-8789

50. Qin N, Bayat AR, Trevisi E, Minuti A, Kairenius P, Viitala S, et al. Dietary supplement of conjugated linoleic acids or polyunsaturated fatty acids suppressed the mobilization of body fat reserves in dairy cows at early lactation through different pathways. J Dairy Sci. 2018;101:795470. https://doi.org/10.3168/jds.2017-14298

51. Knapp JR, Freetly HC, Reis BL, Calvert CC, Baldwin RL. Effects of somatotropin and substrates on patterns of liver metabolism in lactating dairy cattle. J Dairy Sci. 1992;75:1025-35. https://doi.org/10.3168/jds.S0022-0302(92)77846-1

52. Milis C, Liamadis D, Roubies N, Christodoulou V, Giouseljiannis A. Comparison of corn gluten products and a soybean-bran mixture as sources of protein for lactating Chios ewes. Small Rum Res. 2005;58:237-44. https://doi.org/10.1016/j.smallrumres.2004.10.006

53. Wallace JM, Milne JS, Redmer DA, Aitken RP. Effect of diet composition on pregnancy outcome in overnourished rapidly growing adolescent sheep. Brit J Nutr. 2006;96:1060-8. https:// doi.org/10.1017/BJN20061979

54. Majewska MP, Miltko R, Bełżecki G, Skomiał J, Kowalik B. Supplementation of rapeseed and linseed oils to sheep rations: effects on ruminal fermentation characteristics and protozoal populations. Czech J Anim Sci. 2017;62:527-38. https://doi.org/10.17221/9/2017-CJAS

55. Johnson KA, Kincaid RL, Westberg HH, Gaskins CT, Lamb BK, Cronrath JD. The effect of oilseeds in diets of lactating cows on milk production and methane emissions. J Dairy Sci. 2002;85:1509-15. https://doi.org/10.3168/jds.s0022-0302(02)74220-3

56. Gómez-Cortés P, De la Fuente MA, Toral PG, Frutos P, Juárez M, Hervás G. Effects of different forage: concentrate ratios in dairy ewe diets supplemented with sunflower oil on animal performance and milk fatty acid profile.J Dairy Sci. 2011;94:4578-88. https://doi.org/10.3168/ jds.2010-3803

57. Glasser F, Ferlay A, Chilliard Y. Oilseed lipid supplements and fatty acid composition of cow milk: a meta-analysis.J Dairy Sci. 2008;91:4687-703. https://doi.org/10.3168/jds.2008-0987 
58. Isenberg BJ, Soder KJ, Pereira ABD, Standish R, Brito AF. Production, milk fatty acid profile, and nutrient utilization in grazing dairy cows supplemented with ground flaxseed. J Dairy Sci. 2019;102:1294-311. https://doi.org/10.3168/jds.2018-15376

59. Vlaeminck B, Fievez V, Cabrita ARJ, Fonseca AJM, Dewhurst RJ. Factors affecting odd-and branched-chain fatty acids in milk: a review. J Anim Feed Sci Technol. 2006;131:389-417. https://doi.org/10.1016/j.anifeedsci.2006.06.017

60. Correddu F, Gaspa G, Pulina G, Nudda A. Grape seed and linseed, alone and in combination, enhance unsaturated fatty acids in the milk of Sarda dairy sheep.J Dairy Sci. 2016;99:1725-35. https://doi.org/10.3168/jds.2015-10108

61. Kennelly JJ. The fatty acid composition of milk fat as influenced by feeding oilseeds. J Anim Feed Sci Technol. 1996;60:137-52. https://doi.org/10.1016/0377-8401(96)00973-X

62. Caroprese M, Ciliberti MG, Marino R, Santillo A, Sevi A, Albenzio M. Polyunsaturated fatty acid supplementation: effects of seaweed Ascophyllum nodosum and flaxseed on milk production and fatty acid profile of lactating ewes during summer. J Dairy Res. 2016;83:289-97. https://doi.org/10.1017/s0022029916000431

63. Bauman DE, Perfield JW, Lock AL. Effect of trans fatty acids on milk fat and their impact on human health. In: Proceedings of the 19th Southwest Nutrition and Management Conference; 2004; University of Arizona, Tucson, AZ. p. 41-52. 